\title{
PHYSICAL AND CHEMICAL NATURES OF POST ARTISANAL GOLD MINE AREA AT KEBUNLADO VILLAGE OF RIAU PROVINCE
}

\author{
KARAKTER FISIKA DAN KIMIA LAHAN PASCATAMBANG EMAS \\ RAKYAT, DESA KEBUNLADO - PROVINSI RIAU
}

\author{
FAUZUL AMRI ${ }^{1}$, REGINAWANTI HINDERSAH ${ }^{2}$, BENITO R. KURNANI ${ }^{1}$, SUNARDI ${ }^{1}$, \\ MARTHA F. CAHYANDITO ${ }^{1}$ and DEDI NURSYAMSI ${ }^{3}$ \\ ${ }^{1}$ Environmental Studies, Postgraduate School, Padjadjaran University \\ ${ }^{2}$ Department of Soil Science, Faculty of Agriculture, Padjadjaran University \\ Jalan Raya Bandung Sumedang KM.21, Hegarmanah, Jatinangor Sub-district, \\ Sumedang Regency, West Java 45363 \\ e-mail : fauzul amri29@yahoo.com \\ 3 Indonesian Center for Agricultural Land Resources Research and Development \\ Jalan Tentara Pelajar No.12, RT. 2 / RW. 8, Cimanggu, Bogor
}

\begin{abstract}
Illegal artisanal gold mining in Kebunlado, Riau Province has damaged the smallholders estate. The use of mercury for extracting the gold is potentially pollute the soil and syrrounding water as well as threats plantation productivity and it's food chain. The purpose of this research is to study the mining impact towards the physical and chemical properties of the soil around the plantation, and measure the mercury contamination within the tailings, soil and river to be compared with the soil sample near the mine area. Sampling was carried out in 10 locations to study the properties of the land surrounding the artisanal gold mining. Physical and chemical properties of the soil were studied. The samples came from the mine sites (7 samples) and its surrounding area (3 samples). Sampling was conducted using a toposequence transect method, based on its topographical conditions and soil parent material with the purposive method. Mercury level was measured from eight soil samples that were sampled from surrounding artisanal mine area and six water samples from the surrounding rivers. The research showed that the soil characteristics had changed after mining activities. The soil properties were higher in sand, with bulk density and permeability compared to intact soil. However, there was no distinct change in $\mathrm{pH}$, total nitrogen, organic carbon as well as available $\mathrm{P}$, except $\mathrm{C} / \mathrm{N}$ in post mine area was relatively low. Mercury content in the gold mine area was higher than that of the average mercury within the soil around the world. The Mercury in the river stream exceeds the threshold based on Indonesia Regulation. The study suggested that land reclamation is needed to develop oil palm plantation in terms of improving the soil physics, increasing $\mathrm{C} / \mathrm{N}$ and remediation as well as reducing the mercury in soil and water.
\end{abstract}

Keywords: gold mine, mercury, soil physical properties, soil chemical properties, palm oil.

\begin{abstract}
ABSTRAK
Penambangan emas skala kecil di Desa Kebunlado Riau, merusak lahan perkebunan rakyat. Penggunaan merkuri untuk mengekstraksi emas berpotensi mencemari tanah dan air serta mengancam produktivitas tanaman dan rantai makanan. Penelitian ini bertujuan untuk mengkaji dampak penambangan emas terhadap sifat fisik dan kimia tanah serta kontaminasi merkuri di tailing, tanah dan sungai, dan membandingkannya dengan tanah utuh di dekat area sekitar tambang. Pemercontohan dilakukan dengan metode transek toposequent berdasarkan topografi dan bahan induk, dan metode purposive sampling untuk mengidentifikasi 10 lokasi pengambilan sampel tanah yang dipelajari. Penentuan kualitas fisik dan kimia tanah dilakukan pada tujuh sampel di area tambang dan tiga sampel tanah utuh sekitar tambang. Merkuri diukur dari lima sampel tanah terdampak, enam sampel air diambil dari sungai. Hasil penelitian menunjukkan bahwa karakteristik fisik berubah setelah adanya kegiatan tambang emas seperti tanah berpasir, bobot isi dan permeabilitas dibandingkan dengan tanah utuh. Namun tidak ada perubahan $\mathrm{pH}, \mathrm{N}-$ total, C- organik, dan P-tersedia kecuali C/N tanah area tambang yang lebih rendah. Kandungan merkuri
\end{abstract}


tanah di area tambang lebih tinggi daripada rata-rata merkuri tanah di dunia. Aliran sungai mengandung merkuri melebihi ambang batas menurut Peraturan Indonesia. Penelitian menunjukkan bahwa reklamasi tanah diperlukan untuk mendirikan kebun kelapa sawit di Kebunlado untuk memperbaiki sifat fisik tanah dan meningkatkan $\mathrm{C} / \mathrm{N}$; dan remediasi untuk mengurangi ketersediaan merkuri di tanah dan air.

Kata kunci: tambang emas, merkuri, sifat fisik tanah, sifat kimia tanah, kelapa sawit.

\section{INTRODUCTION}

This research was conducted in the post artisanal gold mining area in Kebunlado Village Singingi District, Kuantan Singingi Regency, Riau Province. Geographically, the location study is located between 1010 02' 1010 55' BT and $00 \mathrm{LU}-10 ; 125 \mathrm{~km}$ to the east of Pekanbaru and $35 \mathrm{~km}$ away to the north of Taluk Kuantan (Figure 1).

The gold mining area in Kuantan Singingi Regency achieves 12,413,37 ha (Dinas Energi Sumber Daya Mineral Kabupaten Kuantan Singingi, 2012). The area has been illegally exploited since 2008. Land damage at the mine site is estimated around 7,952 ha performing the largest damage area was at Singingi area around 3,718 ha (Dinas Lingkungan Hidup Kuantan Singingi, 2017). The miners took out the sediment from the river and watershed before extracting the gold with mercury. The waste water flowed into the river which then increased the total solid dissolution and affected the water's color, odor, and taste as well due to the change in its chemical and physical properties. Tailing disposition located in the nearby area covered the top soil and caused mercury contamination to the water stream and soil which finally influenced the food chain.

Mining the mineral causes the loss of top soil, and natural vegetation. Tailing deposited in an Entisol (recent soil) soil was poor in organic carbon and plant nutrients such as nitrogen, phosphorous and potassium; but rich in heavy metals especially in the dry season (Makdoh and Kayang, 2015; Hindersah et al., 2018). The land in abandoned mining generally has a very unstable soil and high content of sand, low $\mathrm{pH}$, high water infiltration, low water retention and high soil temperatures (Yuarsah et al., 2017).

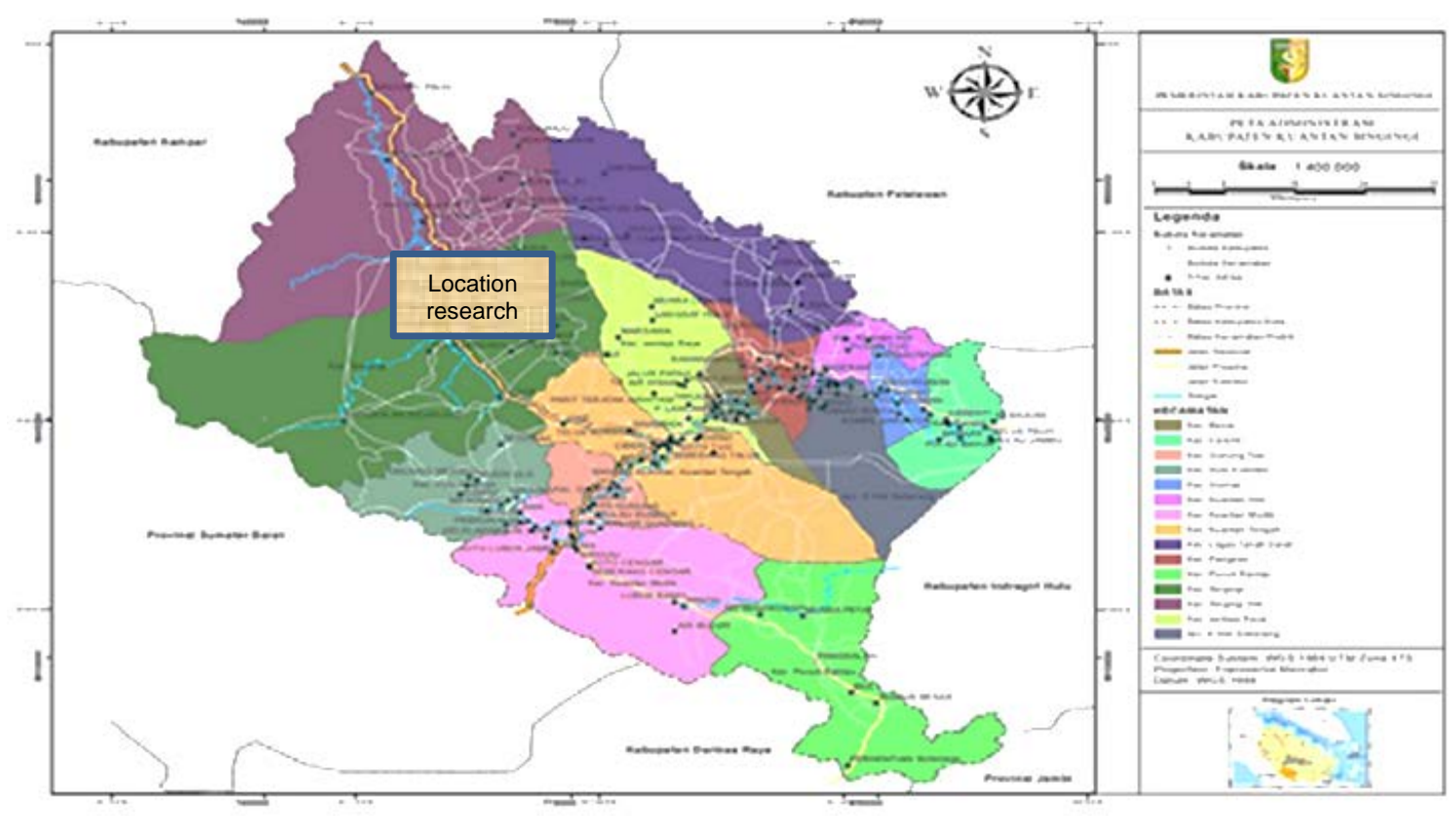

Figure 1. Map of research location in Kuantan Singingi Regency 
The Local communities at Kebunlado village still want to cultivatec the rubber (Hevea brasiliensis) and palm oil (Elaeis guineensis Jacq) in abandoned gold mine. The mining area is then expected to be replanted by palm. The success story in plantation development after restoring the post mining area was demonstrated in Ghana (Festin et al., 2019). In Bangka Island, post tin mining area is currently used for integrated agriculture by the local community (Asmarhansyah et al., 2017). Before using the post mining soil for plantations, chemical, biological and physical improvement such the soil should be carried out through land remediation to enhance its quality. Bioremediation using microorganism and phytoaccumulator plant is suggested to reduce the availability of mercury. The bioremediation strategies using Jatropha curcas has been carried out to a former mine that was abandoned for more than 20 years in Nogpog, Philippines (Aggangan et al., 2017).

In terms of reintroducing high-yielding palm oil plantation, it is necessary to obtain necessary information of soil quality and ensure the growth and the production of palm oil. The objective of the study is to assess the impact of gold mining on the physical and chemical properties of the soil as well as the contamination due to mercury leaching from the tailings which polluted the soil and river streams of Kebunlado village, compared to the soil properties in rubber and palm oil near the gold mine area.

\section{METHOD}

The samples were taken from affected mine area (710 ha) and non affected mining area, namely from oil palm and rubber plantations area that cover 1 ha (Figure 2) and the postmining activities area of the Meander river as well. All sampling points were selected by transect method combined with a toposequence and purposive sampling.

The parent materials of post-mining area includes sand, clay and gravel deposits which belongs to $\mathrm{C}$ horizon (parent material or weathered parent rock) and $\mathrm{R}$ (parent rock) without $A$ or $B$ horizon. The seven sampling points from post mine area were located at the altitude of 52-58 $\mathrm{m}$ above sea level; and all samples showed different soil effective depth, water level and vegetation as shown in Table 1. Tree naturally grown between the grasses and bushes were Senduduk (Melastoma malabathricum) and Acacia (Acacia mangium) trees.

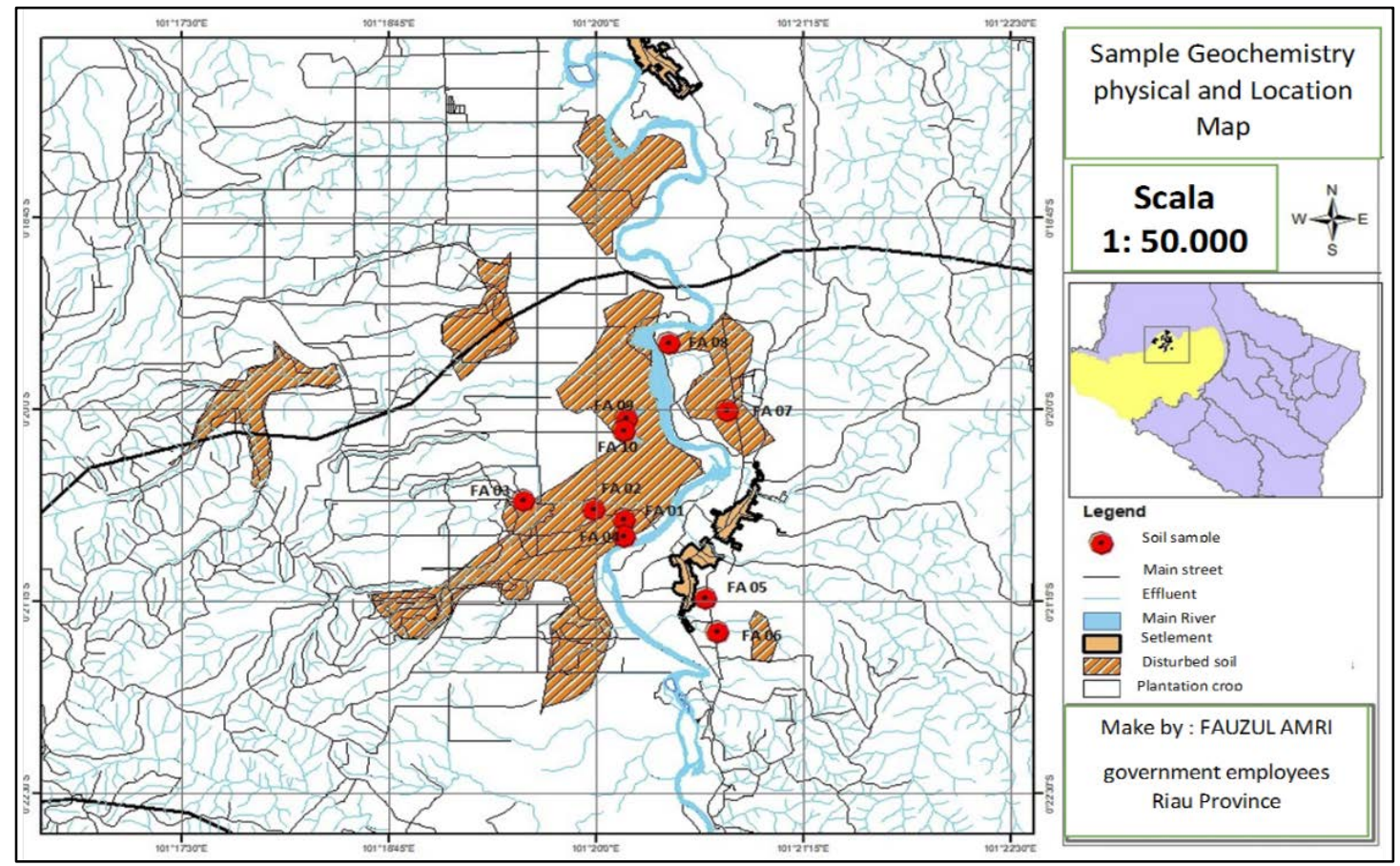

Figure 2. Sampling location at the post gold mine are and non affected soil nearby post mining area 
Physical and Chemical Properties Natures of Post Artisanal Gold Mine Area ... Fauzul Amri et al.

Table 1. Charactersitics of area affected by gold mine at Kebunlado village

\begin{tabular}{lccccccc}
\hline \multicolumn{1}{c}{ Land } & \multicolumn{7}{c}{ Sampling Points } \\
\cline { 2 - 8 } \multicolumn{1}{c}{ Characteristics } & F.01 & F.02 & F.05 & F.06 & F.07 & F.08 & F 09 \\
\hline Effective depth (cm) & 25 & 40 & 100 & 50 & 100 & 40 & 100 \\
Water level (cm) & -25 & -40 & -60 & -60 & - & - & - \\
Vegetation & Grass & bush & Bare & Grass & $\begin{array}{c}\text { Palm oil } \\
\text { and bush }\end{array}$ & Palm oil & bush \\
\hline
\end{tabular}

Soil sampling was also carried out in the rubber and oil palm plantation which is not affected by mining activities. The altitude of the area was 52-61 $\mathrm{m}$ above sea level. A total of three soil samples were taken from the three sampling locations at the plantation area. The soil was characterized as Fluvic Gleisol and Dystric Cambisol - both is mostly located in the river flood plain, and Oxic Cambisol found in the tectonic plain (Table 2).

Samples for soil physical analysis have been taken from six sampling points in the post gold mine area (Sample codes of F.01, F.05, F.06, F.07, F.08 and F.09) and three sampling points in the intact soil of rubber and palm oil plantation areas which were not affected by gold mine activities (Sample code of F.03, F.04, F.10). Soil chemical measurements were carried out to seven soil samples from affected areas (Sample codes of F.01, F.02, F.05, F.06, F.07, F.08 and F. $09)$ and three of them from unaffected areas (Sample codes of F 03, F 04, F 10).

Soil physical analysis was taken by ring sampler; whereas for chemical analysis the sample was taken from $0-20 \mathrm{~cm}, 20-40 \mathrm{~cm}$ and $20-60 \mathrm{~cm}$ at each observation point using an auger. All soil samples were conducted by composite sampling method and stored in a sealed plastic bag. Soil sample from intact soil near mine area was taken from $0-20 \mathrm{~cm}$ and $20-100 \mathrm{~cm}$ based on the color of each layer. The weight of each sample was $500 \mathrm{~g}$.

Analysis of physical and chemical properties was carried out at Soil Science Laboratory, Riau University; while mercury analysis was carried out at Research Institute for Standardization (Baristand) Industry at Padang, West Sumatra.

The observed properties of soil physical were texture, bulk density (BD), particle density (PD) and total pore space (TRP), while the observed chemical properties were $\mathrm{pH}\left(\mathrm{H}_{2} \mathrm{O}\right.$ and $\mathrm{KCL}$ ), N-total, P-available, C-organic, Redox, Electrical conductivity, Cation Exchange Capacity, $\mathrm{C}$ to $\mathrm{N}$ ratio, and mercury. Analysis method is depicted in Table 3. Before analysis, soil sample was air dried for 4 days and grounded up to $0.5 \mathrm{~mm}$.

Water samples were collected from meander area of the river in Kebonlado area at which the miners disposed their mine waste into the waters. The volume of water sample was 500 $\mathrm{mL}$ each.

Results of soil analysis were then compared to the soil quallity standard belongs to Indonesian Center for Agricultural Land Resources Research and Development.

Table 2. Soil charactersitic of the intact soil near gold mine area

\begin{tabular}{lccc}
\hline \multicolumn{1}{c}{ Soil Properties } & \multicolumn{3}{c}{ Sampling Points } \\
\cline { 2 - 4 } & F.03 & F.04 & F.10 \\
\hline Soil Classification & Oxic Cambisol & Fluvic Gleisol & District Cambisol \\
Effective Depth $(\mathrm{cm})$ & 60 & 61 & 52 \\
Water surface $(\mathrm{cm})$ & 62 & 86 & 100 \\
Vegetation & Oil Palm & Rubber & Palm oil \\
Parent Material & Acid felsic mixture & Deposited clay, sand, & $\begin{array}{c}\text { Deposited sand, clay, } \\
\text { gravel }\end{array}$ \\
\hline
\end{tabular}


Table 3. Methods for analyzing the physical and chemical parameters

\begin{tabular}{|c|c|}
\hline Parameter & Analysis Method \\
\hline Bulk Density (BD) $\left(\mathrm{g} / \mathrm{cm}^{3}\right)$ & Gravimetry \\
\hline Particle density (PD) $\left(\mathrm{g} / \mathrm{cm}^{3}\right)$ & Gravimetry \\
\hline Total Pore Space (TRP) (\%) & TRP $=(1-(B D / P D) \times 100 \%)$ \\
\hline Texture (\%) & Pipette \\
\hline CEC (me/ 100g ) & $\mathrm{NH}_{4} \mathrm{OAc}$ Extract $\mathrm{pH} 7$ \\
\hline $\mathrm{pH} \mathrm{H}_{2} \mathrm{O}$ and $\mathrm{KCl}$ & Potentiometry \\
\hline C-Organic (\%) & Walkley and Black \\
\hline $\mathrm{N}-$ Total $(\%)$ & Kjeldahl \\
\hline P-Available $(\mathrm{mg} / \mathrm{kg})$ & Bray \\
\hline $\mathrm{DHL}(\mathrm{ds} / \mathrm{m})$ & Electrical conductivity \\
\hline Redox (mV) & Electrochemical potential \\
\hline $\mathrm{C} / \mathrm{N}$ & Calculation \\
\hline Mercury $(\mathrm{Hg})$ & Atomic Absorption Spectrophotometer after Mixed acid extraction \\
\hline
\end{tabular}

\section{RESULTS AND DISCUSSION}

\section{Physical properties}

Based on the results of the analysis the physical properties of the affected and unaffected soils are shown in Table 4.

\section{Texture}

After gold mining activity, the upper horizon of soil was $C$ horizon with the depth up to $100 \mathrm{~cm}$. In unaffected area the $A$ and $B$ horizon were remain undamaged. The difference within horizons of two sampling points caused a change in soil texture (Table 4). The post mine soil texture becomes coarser than that of the origina one. This change was caused by the increase in sand particle and the decrease in clay and dust. Fine clay texture in affected land was found in F 05, F 06 and F 09 from swamp area where the clay-rich river sediments has been deposited (Fahmi and Wakhid, 2018). The clay rich soil will inhibit the plant roots penetration since the air movement was restricted as result, the waterlogged might be occurred (Tambunan, 2008).

Table 4. Some soil physical properties in post mine area

\begin{tabular}{|c|c|c|c|c|c|c|c|c|c|c|}
\hline \multirow{2}{*}{$\begin{array}{l}\text { Sampling } \\
\text { Point }\end{array}$} & \multirow{2}{*}{$\begin{array}{c}\text { Soil } \\
\text { Depth } \\
(\mathrm{cm})\end{array}$} & \multicolumn{3}{|c|}{ Land Fraction (\%) } & \multirow[b]{2}{*}{ Texture } & \multirow{2}{*}{$\begin{array}{c}\text { Bulk } \\
\text { Density } \\
\left(\mathrm{g} \mathrm{cm}^{3}\right)\end{array}$} & \multirow{2}{*}{$\begin{array}{c}\text { Density } \\
\text { Particles } \\
\left(\mathrm{g} \mathrm{cm}^{3}\right)\end{array}$} & \multirow{2}{*}{$\begin{array}{l}\text { Total Pore } \\
\text { Space (\%) }\end{array}$} & \multirow[b]{2}{*}{ Drainage } & \multirow[b]{2}{*}{ Permeability } \\
\hline & & Sand & Silt & clay & & & & & & \\
\hline \multicolumn{11}{|c|}{ Soil in Gold Mine Area } \\
\hline F 01 & $0-25$ & 89.4 & 4.26 & 6.33 & Sand & 1.72 & 2.11 & 18.5 & $\begin{array}{c}\text { Slightly } \\
\text { quick }\end{array}$ & Rapid \\
\hline F 05 & $0-100$ & 19.3 & 42.0 & 38.7 & Silty clay & $\mathrm{n}$ & $\mathrm{n}$ & $\mathrm{n}$ & Slow & Average \\
\hline F 06 & $0-50$ & 46.3 & 22.9 & 30.8 & Clay loam & $\mathrm{n}$ & $n$ & $n$ & $\begin{array}{l}\text { Slightly } \\
\text { slow }\end{array}$ & Average \\
\hline $\mathrm{F} 07$ & $0-43$ & 84.6 & 8.91 & 6.5 & sand & $\mathrm{n}$ & $\mathrm{n}$ & $\mathrm{n}$ & $\begin{array}{l}\text { Slightly } \\
\text { quick }\end{array}$ & Rapid \\
\hline F 08 & $0-40$ & 80.9 & 8.56 & 10.5 & $\begin{array}{l}\text { Sandy } \\
\text { loam }\end{array}$ & 1.50 & 2.89 & 48.1 & $\begin{array}{l}\text { Slightly } \\
\text { quick }\end{array}$ & Rapid \\
\hline F 09 & $0-60$ & 50.9 & 19.6 & 29.5 & $\begin{array}{l}\text { Sandy } \\
\text { loam }\end{array}$ & $\mathrm{n}$ & $\mathrm{n}$ & $\mathrm{n}$ & Well drain & Average \\
\hline \multicolumn{11}{|c|}{ Intact Soil Near Mine Area } \\
\hline \multirow{2}{*}{ F 03} & $0-21$ & 48.5 & 18.2 & 33.3 & $\begin{array}{l}\text { Sandy } \\
\text { loam }\end{array}$ & 1.09 & 2.10 & 48 & \multirow{2}{*}{ Well drain } & \multirow{2}{*}{ Average } \\
\hline & $22-62$ & 49.1 & 31.7 & 19.2 & $\begin{array}{l}\text { Sandy } \\
\text { loam }\end{array}$ & 1.75 & 2.34 & 25.2 & & \\
\hline \multirow[t]{2}{*}{ F 04} & $0-16$ & 51.2 & 20.1 & 28.7 & $\begin{array}{l}\text { Sandy } \\
\text { loam }\end{array}$ & 1.40 & 2.27 & 38.2 & \multirow{2}{*}{$\begin{array}{l}\text { Slightly } \\
\text { slow }\end{array}$} & \multirow[t]{2}{*}{ Average } \\
\hline & $17-60$ & 46.4 & 33.6 & 20.1 & Clay & 1.56 & 2.40 & 35 & & \\
\hline \multirow{2}{*}{$\mathrm{F} 10$} & $0-18$ & 42.6 & 18.7 & 38.7 & Clay & 1.55 & 2.30 & 32.6 & \multirow{2}{*}{ Well drain } & \multirow{2}{*}{ Average } \\
\hline & $19-60$ & 13.5 & 38.1 & 48.3 & Dusty clay & 1.17 & 2.20 & 46.8 & & \\
\hline
\end{tabular}

$\mathrm{n}$, not analyzed 


\section{Bulk Density, Particle Density and Pore Space}

The bulk density of soil in gold mine area was $1.5-1.7 \mathrm{~g} / \mathrm{cm}^{3}$, while in the unaffected soil at depth of $0-20 \mathrm{~cm}$ and $20-100 \mathrm{~cm}$ were 1.09 $1.4 \mathrm{~g} / \mathrm{cm}^{3}$ and $1.55-1.75 \mathrm{~g} / \mathrm{cm}^{3}$ respectively (Table 4). The soil texture in the gold mine was coarser than that in unaffected area. The bulk density was affected by soil texture. Sandy soils had higher bulk density than that of fine textured soil. Soil aggregation due to transportation or tillage operation might increase the bulk density but did not affect the texture. In general, the bulk density of coarse soil was $>1.3 \mathrm{~g} / \mathrm{cm}^{3}$, while fine soil was $<1.3$ $\mathrm{g} / \mathrm{cm}^{3}$ and clay soil had bulk density of 1.3 $\mathrm{g} / \mathrm{cm}^{3}$ (Hanafiah, 2012). The soil bulk density the restored open mining area of Meghalaya India with coarse parent material was ranging from 1.3-1.75 g/cm $3 \mathrm{~cm}^{3}$ (Bhuyan and Momin, 2015).

The artisanal gold mine area had a particle density ranging from 2.11 to $2.89 \mathrm{~g} / \mathrm{cm}^{3}$ (Table 4). Particle density was determined by bulk density (Sutanto, 2005). Soil in F 01 had a high bulk density, but low in particle density due to high water content in soil during the rainy season at the time soil was sampled. Soil with high particle density reduced the availability of water, air exchange in the soil, and infiltration capacity (Tambunan, 2008). The total pore space in the affected area was $18-48 \%$ while in the non-affected one at depth of 0-20 cm was 32.6-48 \% and at depth of $20-100 \mathrm{~cm}$ was $25.2-46.6 \%$. Fine-textured soil will have a higher total pore percentage than the coarse-one; soil porosity for optimal plant growth was > 50\% (Kusuma, Izzati and Saptiningsih, 2013).

\section{Drainage and Permeability}

At $F 01, F 07$ and $F 08$ sampling points located in the areas affected by artisanal gold mine, the drainage was quick due to the amount of sand texture at that location. The soil was not able to hold water for appropriate growth of plant (Masria, 2015). In contrast, drainage in F 06 and F 09 soils was slower since the soil contain a higher clay. Soil drainage determines the direction and rates of water and nutrient movement within soil (Abd-Elmabod et al., 2017). High content of clay will limit the $\mathrm{O}_{2}$ for root respiration which in hibits reproduction processes (Intara et al., 2011).
The soil permeability level in the affected land was moderate to rapid while that in the unaffected one was moderate (Table 4). The velocity of water that moved downward will be faster in soil dominated by sand since the total macro pores was higher than that in the total micro pores. As a result, soil passed the water to the lower layers very quick (Mirdat, Patádungan and Isrun, 2013). Macro pores drained down the air and water, whereas micro pores inhibited the air movement.

Overall, changes the physical properties in post artisanal gold mine soil are summarized in Table 5. Physically, the soil became coarser due to the increase of sand fraction; and would be unable to retain soil water movement downward compared to the unaffected soil.

Limited water in soil will limited chemical and biological reactions that provides plant nutrients. Usually, sand fraction dominated the soil is low in organic matter (Henrianto, Okalia and Mashadi, 2019) and susceptible to severe erosion (Allo, 2016). Soil with a sandy texture is not suitable for palm oil plantation as the roots of palm oil is shallow. The palm oil are relatively less tolerant to the dry soil (Antari, Wawan and Manurung, 2014). On the contrary, the palm oil have a better growth in a good texture unaffected soil; sandy loam soil will provide nutrients but organic matter revision is needed to improve the soil porosity, soil $\mathrm{pH}, \mathrm{CEC}$, and $\mathrm{P}$ availability. Oil palm plants are quite tolerant to waterlogged soils and high content clay soil (da Ponte et al., 2019).

Table 5. Changes in physical properties before and after gold mining

\begin{tabular}{ccc}
\hline Feature & Before & After \\
\hline Upper Horizon: & $\begin{array}{c}\text { Horizon A } \\
(0-20 \mathrm{~cm}) \\
\text { Horizon B } \\
(20-100 \mathrm{~cm})\end{array}$ & $\begin{array}{c}\text { C horizon }(0- \\
100 \mathrm{~cm}) \\
\text { Rock }\end{array}$ \\
$\begin{array}{c}\text { Sandy loam } \\
\text { Well } \\
\text { Dexture }\end{array}$ & $\begin{array}{c}\text { Sand } \\
\text { Quick drain }\end{array}$ \\
drainage & Rapid \\
\hline
\end{tabular}

\section{Chemical Properties}

The chemical properties of $C$ horizon in post artisanal gold mine as well as in the $A$ and $B$ horizon of plantation area that were not 
affected by the artisanal gold mine activity is shown in Table 6 . The soil in unaffected area was slightly acid compared to the affected area where the soil $\mathrm{pH}$ was increased. The increase in acidity was also demonstrated in post artisanal mining land in Ohio; where the reclaimed soil had a $\mathrm{pH}$ of 4.9-8.1, while the intact land around the mine recorded $\mathrm{pH}$ ranging from 4.6-7,0 (Shrestha and Lal, 2011). The parent materials of post artisanal mine area were sand, clay and gravel; after mining, the $\mathrm{C}$ horizon appeared to the surface. Sand and gravel could be slightly acid.

The chemical properties of the soil in gold mine area were similar to the intact areas around the mine. The soil component consisted of total nitrogen, $P$ available, organic carbon: electrical conductivity. Potential redox as well as Cation Exchange Capacity were not changed but the $\mathrm{C} / \mathrm{N}$ ration of the intact soil around the mine was higher than that of the post mine area. Low $\mathrm{C} / \mathrm{N}$; determines that the nitrogen is mobile and easily uptaken by plants; without fertilization, the plant growth will be limited by nitrogen. The critical $\mathrm{C} / \mathrm{N}$ for enzymatic decomposition is below 30, above that the organic matter, it will be difficult to decompose (Guo et al., 2012). A good $\mathrm{C} / \mathrm{N}$ is 20-30 and will stable when reaching a ratio of 15 (Djuarnani, Kristian and Setiawan, 2009). Electrical conductivity lower than the limit of 4 $4.0 \mathrm{mS} / \mathrm{cm}$ indicates that the land is classified as non-saline soil so the plant roots are enable to uptake enough water for plant growth (Muliawan, Sampurno and Jumarang, 2016). Redox potential (Eh) of soil was $67-103 \mathrm{mV}$ which showed that all soil were moderately reduced and will limit the plant growth (Husson, 2013).
The top soil in mine area was currently covered by vegetation which included roots as well as litters that decomposed into soil organic matter as source of total nitrogen. The plant including stems, twigs, and leaves will be decomposed enzymatically and mixed with soil and then increase the availability of soil nitrogen (Hamid, Priatna and Hermawan, 2017).

The availability of phosphorus $(P)$ in soil of post artisanal gold mine was moderate to very high but the $P$, available at the intact soil near mine area, was low to high as presented in Table 6. For soil with low $\mathrm{P}$, the application of phosphorous fertilizer and organic matter is needed. The addition of organic matter will also increase the availability of $P$ in the soil which is influenced by the amount of clay, cation exchange capacity, humidity, temperature, aeration and soil pH (Sari, Sudarsono and Darmawan, 2017).

In all samplings, the organic carbon level was low to high (Table 6). The organic carbon in intact soil (rubber and palm oil plantation) was depended on the soil horizon and the level of organic carbon in A horizons were higher than that in $B$ horizon as shown in Table 6. Low organic carbon in sampling point at the mining area was due to the erosion and the higher organic carbon influenced by overgrown vegetation (Purnamayani, Hendri and Purnama, 2016). The organic carbon is an intergral part of heterotrophic microbe metabolism. The application of manure or humus will be valuable to increase nutrient cycle accomplished by soil microbes.

Table 6. Chemical properties of soil in gold mine and intact areas

\begin{tabular}{ccccccccccccc}
\hline Chemical & \multicolumn{3}{c}{ Sampling points in post mine soil (C Horizon) } & \multicolumn{3}{c}{ Sampling points in intact soil (A and B Horizon) } \\
properties & F 01 & F 05 & F 06 & F 07 & F 08 & F 09 & F 03 & F 03 & F 04 & F 04 & F 10 & F 10 \\
\hline Depth (cm) & $0-25$ & $0-40$ & $0-50$ & $0-60$ & $0-40$ & $0-60$ & $0-21$ & $21-62$ & $0-16$ & $17-60$ & $0-18$ & $19-60$ \\
pH ( H $_{2}$ O) & 5.6 & 3.9 & 4.3 & 5.7 & 5.1 & 4.5 & 4.4 & 4.8 & 4.5 & 4.6 & 4.3 & 4.7 \\
pH (KCl) & 5.0 & 3.9 & 4.2 & 4.9 & 4.7 & 4.3 & 4.4 & 4.6 & 4.4 & 4.4 & 4.1 & 4.1 \\
N- Total (\%) & 0.30 & 0.34 & 0.33 & 0.31 & 0.35 & 0.37 & 0.31 & 0.33 & 0.29 & 0.32 & 0.35 & 0.32 \\
P-Available & & & & & & & & & & & & \\
(mg/kg) & 22.6 & 16.9 & 18.9 & 46.6 & 12.1 & 79.3 & 24.2 & 31.0 & 10,9 & 11.6 & 22.8 & 13.1 \\
C-Organic (\%) & 1.18 & 3.30 & 1.84 & 1.59 & 2.15 & 2.48 & 2.23 & 1.84 & 1.91 & 1.54 & 3.89 & 3.38 \\
Redox (mV) & 69 & 132 & 101 & 67 & 82 & 80 & 96 & 86 & 82 & 78 & 103 & 76 \\
EC (ds/m) & 0.06 & 0.11 & 0.11 & 0.07 & 0.06 & 0.07 & 0.08 & 0.07 & 0.07 & 0.07 & 0.07 & 0.07 \\
CEC (me/ 00g) & 20.6 & 29.9 & 21.3 & 20.8 & 23.7 & 26.9 & 23.6 & 21.5 & 24.6 & 21.6 & 24.1 & 19.4 \\
C/N & 3,9 & 9.7 & 5.6 & 5.1 & 6.1 & 6.7 & 7.19 & 5.57 & 6.59 & 4.81 & 11,1 & 10.6 \\
\hline
\end{tabular}

pH: soil acidity; N: Nitrogen; P: Phosphate; C: Carbon; EC: Electrical conductivity; CEC: Cation Exchange Capacity; Critical threshold of EC > $4.0 \mathrm{mS} / \mathrm{cm}$; Redox <200 mV (Government Regulation no. 150 year 2000) 
In general, the value of CEC in the affected land of gold mines is classified as moderate to high as shown in Table 6. Affected land that was covered with grass and shrubs generally had a high CEC. This was due to the amount of organic matter in soil derived from roots and decay plants (Soepardi, 2005). The Soil which has moderate to high CEC has a low ability to absorb and provide nutrients for plants (Hardjowigeno, 2007).

Low $\mathrm{C} / \mathrm{N}$ is known for determining the ease in overhauling the organic material which is easily absorbed by plants. The critical value of $\mathrm{C} / \mathrm{N}$ ratio for decomposition is below 30, above the organic material will be difficult to decompose (Guo et al., 2012). A good C/N ratio between 20-30 will be stable when reaching a ratio of 15 (Djuarnani, Kristian and Setiawan, 2009).

The difference in chemical properties between soil of mine area and intact area is shown in Table 7. Soil acids in affected land become very acid on sand textured soil because the topsoil was mixed with the subsoil. While soil at impacted land with clay texture had a very acidic soil due to the wet organic matter. C-organic in affected land is classified as low in sand-textured soils and high in clay-textured soils. Former gold mine in Kuantan Singingi Regency showed that the chemical properties of $\mathrm{N}, \mathrm{P}, \mathrm{K}, \mathrm{CEC}, \mathrm{C}$ organic were categorized low while the $\mathrm{C} / \mathrm{N}$ ratio was high for all regions (Aryanti and Hera, 2019).

Table 7. Changes in chemical properties before and after gold mining

\begin{tabular}{|c|c|c|c|c|}
\hline \multicolumn{3}{|c|}{ Unaffected Gold Mine Area } & \multicolumn{2}{|c|}{ Gold Mine Area } \\
\hline Parameter & Value & Quality & Value & Quality \\
\hline $\mathrm{pH}\left(\mathrm{H}_{2} \mathrm{O}\right)$ & $\begin{array}{c}4.30- \\
4.86\end{array}$ & Acid & $\begin{array}{c}3.99- \\
5.57\end{array}$ & $\begin{array}{l}\text { Acid to } \\
\text { slightly } \\
\text { acid }\end{array}$ \\
\hline $\begin{array}{c}\text { EC (Me/ } \\
100 \mathrm{~g})\end{array}$ & $\begin{array}{c}19.4- \\
24.6\end{array}$ & Moderate & $\begin{array}{c}20,6- \\
29,9\end{array}$ & $\begin{array}{c}\text { Moderate } \\
\text { to high }\end{array}$ \\
\hline C-Organic & $\begin{array}{c}1.84- \\
3.89\end{array}$ & $\begin{array}{l}\text { Low to } \\
\text { high }\end{array}$ & $\begin{array}{c}1.18- \\
3.30\end{array}$ & $\begin{array}{l}\text { Low to } \\
\text { high }\end{array}$ \\
\hline
\end{tabular}

Developing palm oil plantation was very possible with adding plant nutrients by using inorganic fertilizer as well as biofertilizer. Organic fertilizer should be added to lower the soil permeability and improve the aggregate. Palm oil (Elaeis guineensis Jacq) requires large quantities of macro nutrients in nitrogen, phosphorous and potassium to produce optimal quantity and quality of fruit. In addition, soil $\mathrm{pH}$ should be acid between $4,0-6,0$ because the optimum growth of oil palm is in soil acidity of (5.0 - 5.5) (Hasriyanti, Abbas and Leo, 2016).

\section{Mercury Content}

The mercury level was analyzed only in the soil of gold mine area in Kebunlado Village at the depth of $0-60 \mathrm{~cm}$. Those were $0.99-1.31$ $\mathrm{mg} / \mathrm{kg}$ as shown in Figure 3. The amount of mercury content in the soil depends on its parent material and depth. The normal range of $\mathrm{Hg}$ in soil is $0.01-0.5 \mathrm{mg} / \mathrm{kg}$ and the critical soil concentration is $0.3-5 \mathrm{mg} / \mathrm{kg}$ (Alloway, 1995). This high level of mercury content was caused by inappropriate management of $\mathrm{Hg}$ containing tailings at the mine site.

Tailing and wastewater contaminated by $\mathrm{Hg}$ were discharged directly into the environment. Measurement of $\mathrm{Hg}$ levels in the standing water of mine area and the river course was ranged from $0.0093-0.2102 \mathrm{mg} / \mathrm{L}$ as shown in Figure 4. It was higher than that in the threshold of Government Law No. 82 of 2001 which is $0.001 \mathrm{mg} / \mathrm{L}$ in waters.

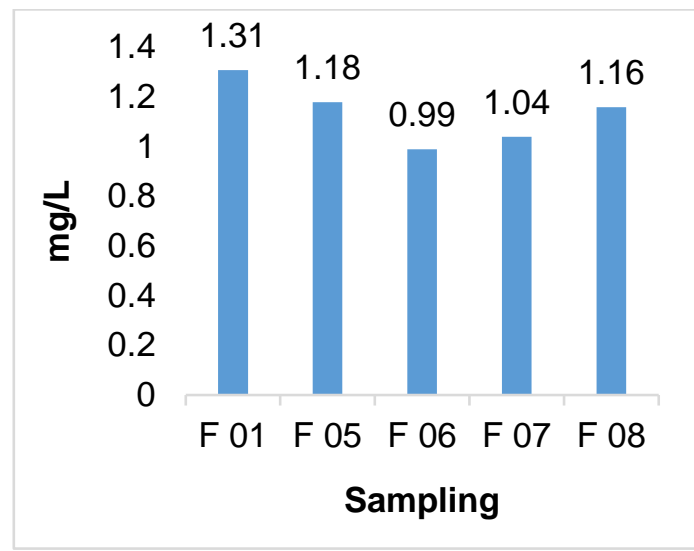

Figure 4. Hg levels in soil of post gold mine area

The level of $\mathrm{Hg}$ sediment at the gold mine site at Kari Kuantan Singingi Regency in 2018, has the high range of 2.4 - 4.17 ppm (Aryanti and Hera, 2019). Hg levels at Buru Regency in the end of 2014 were classified as high in both sediment and water. The concentration of mercury in deposited tailing on agricultural soil at the nearby gold mine of Wamsait village, Waeapo District at Buru Island Maluku was up to $166.1 \mathrm{mg} / \mathrm{kg}^{1}$ (Hindersah et 
al., 2018). The amount of mercury in tailing and waste water found in Anthoni River was identified at 0.021 and $0.64 \mathrm{mg} / \mathrm{kg}$ respectively.

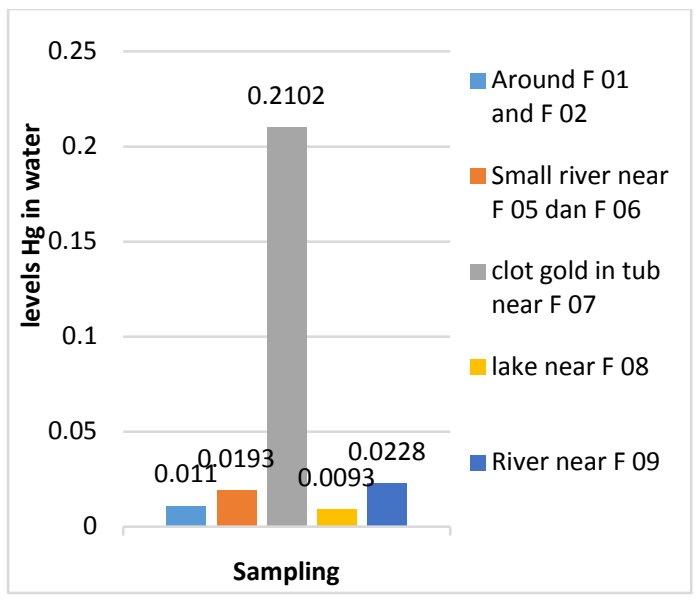

Figure 5. Mercury levels in river of gold mine area

\section{CONCLUSION AND SUGGESTION}

The results showed that the soil in post artisanal gold mine area had changed physically. The A and B horizon had been disappearing and $C$ horizon becomes a top soil with the depth of $0-100 \mathrm{~cm}$ depend on sampling location. Soil became coarser due to the increase of sand fraction which induced quick drain and rapid permeability. These physical properties in the soil would reduce the ability to move water downward compared to intact soil near gold mine area.

The chemical properties of soil in gold mine area were similar with soil in intact land around the mine. Soil traits consisted total nitrogen, $P$ available, organic carbon, electrical conductivity, potential redox as well as Cation Exchange Capacity were not stay the same but $\mathrm{C} / \mathrm{N}$ ratio of intact soil around the mine was higher than the one in post mine area. The content of mercury in soil within gold mine area was higher theb that of mercury concentration. Mercury levels in water stream along the Meander River near gold mine was exceed the government standards. Chemical properties of the soil generally support palm oil plantations in areas affected by gold mine, but planting palm oil in the areas with low C-organic and $\mathrm{C} / \mathrm{N}$ ratio needs intensive application of organic fertilizer as well as nitrogen fertilizer. To develop palm oil plantation, in situ bioremediation should be carried out to decrease mercury concentration.

\section{ACKNOWLEDGEMENT}

The authors are very grateful to Center for Agricultural Land Resources in Bogor for their support during soil survey and sampling. Thanks also to Agronomy Laboratory of Riau University in Pekanbaru, as well as Research Institute for Standardization in Padang for laboratory support.

\section{REFERENCES}

Abd-Elmabod, S. K., Jordán, A., Fleskens, L., Phillips, J. D., Muñoz-Rojas, M., van der Ploeg, M., Anaya-Romero, M., El-Ashry, S. and de la Rosa, D. (2017) 'Modeling agricultural suitability along soil transects under current conditions and improved scenario of soil factors', in Soil Mapping and Process Modeling for Sustainable Land Use Management. Elsevier, pp. 193-219. doi: 10.1016/B978-0-12805200-6.00007-4

Aggangan, N., Cadiz, N., Llamado, A. and Raymundo, A. (2017) 'Jatropha curcas for bioenergy and bioremediation in mine tailing area in Mogpog, Marinduque, Philippines', Energy Procedia, 110, pp. 471-478.

doi: 10.1016/j.egypro.2017.03.171.

Allo, M. K. (2016) 'Kondisi sifat fisik dan kimia tanah pada bekas tambang nikkel serta pengaruhnya terhadap pertumbuhan trengguli dan mahoni', Jurnal Hutan Tropis, 4(2), pp. 207-217.

Alloway, B. J. (ed.) (1995) Heavy metals in soils. Dordrecht: Springer Netherlands. doi: 10.1007/978-94-011-1344-1.

Antari, A., Wawan and Manurung, G. M. E. (2014) 'Pengaruh pemberian mulsa organik terhadap sifat fisik dan kimia tanah serta pertumbuhan akar kelapa sawit', Jurnal Online Mahasiswa Fakultas Pertanian Universitas Riau, 1(1), pp. 1-3.

Aryanti, E. and Hera, N. (2019) 'Sifat kimia tanah area pasca tambang emas: (Studi kasus pertambangan emas tanpa izin di Kenegerian Kari Kecamatan Kuantan Tengah, Kabupaten Kuantan Singingi)', Jurnal Agroekoteknologi, 9(2), pp. 21-26.

Asmarhansyah, A., B Badayos, R., B Sanchez, P., C Sta Cruz, P. and M Florece, L. (2017) 'Land suitability evaluation of abandoned 
tin-mining areas for agricultural development in Bangka Island, Indonesia', Journal of Degraded and Mining Lands Management, 04(04), pp. 907-918. doi: 10.15243/jdmlm.2017.044.907.

Bhuyan, S. I. and Momin, K. G. (2015) 'Role of soil physical properties in Ecological restoration of coal mine land: A study in East Garo hills, Meghalaya', Bhuyan, S. I. and Momin, K,G, 5(4), pp. 681-687.

Dinas Energi Sumber Daya Mineral Kabupaten Kuantan Singingi (2012) Annual report. Taluk Kuantan: Dinas Energi Sumber Daya Mineral Kabupaten Kuantan Singingi.

Dinas Lingkungan Hidup Kuantan Singingi (2017) Identifikasi penambangan liar. Taluk Kuantan.

Djuarnani, N., Kristian and Setiawan, B. S. (2009) Cara cepat membuat kompos. Jakarta: AgroMedia Pustaka.

Fahmi, A. and Wakhid, N. (2018) 'Karakteristik lahan rawa', in Agroekologi Rawa. Depok: PT Rajagrafindo Persada, pp. 91-118.

Festin, E. S., Tigabu, M., Chileshe, M. N., Syampungani, S. and Odén, P. C. (2019) 'Progresses in restoration of post-mining landscape in Africa', Journal of Forestry Research, 30(2), pp. 381-396. doi: 10.1007/s11676-018-0621-x.

Guo, R., Li, G., Jiang, T., Schuchardt, F., Chen, T., Zhao, Y. and Shen, Y. (2012) 'Effect of aeration rate, $\mathrm{C} / \mathrm{N}$ ratio and moisture content on the stability and maturity of compost', Bioresource Technology, 112 , pp. 171-178. doi: 10.1016/j.biortech.2012.02.099.

Hamid, I., Priatna, S. J. and Hermawan, A. (2017) 'Karakteristik beberapa sifat fisika dan kimia tanah pada lahan bekas tambang timah', Jurnal Penelitian Sains, 19(1), pp. 19105-23-19105-31.

Hanafiah, K. A. (2012) Dasar-dasar ilmu tanah. Depok: Rajawali Pers.

Hardjowigeno, S. (2007) IImu tanah. Jakarta: Akademika Presindo.

Hasriyanti, Abbas, I. and Leo, M. N. Z. (2016) 'Aplikasi peta jenis tanah dalam mengidentifikasi lahan berpotensi untuk perkebunan kelapa sawit di Kecamatan Cendana Kabupaten Enrekang', Jurnal Pendidikan Geografi, 21(1), pp. 12-21.
Henrianto, A., Okalia, D. and Mashadi, M. (2019) 'Uji beberapa sifat fisika tanah bekas tambang emas tanpa izin ( PETI) di tiga kecamatan di daratan sepanjang Sungai Kuantan', JURNAL AGRONOMI TANAMAN TROPIKA (JUATIKA), 1(1), pp. 19-31. doi: 10.36378/juatika.v1i1.41.

Hindersah, R., Asda, K., Herdiyantoro, D. and Kamaluddin, N. (2018) 'Isolation of mercury-resistant fungi from mercurycontaminated agricultural soil', Agriculture, 8(3), p. 33. doi: 10.3390/agriculture8030033.

Husson, O. (2013) 'Redox potential (Eh) and pH as drivers of soil/plant/microorganism systems: a transdisciplinary overview pointing to integrative opportunities for agronomy', Plant and Soil, 362(1-2), pp. 389-417.

Intara, Y. I., Sapei, A., Erizal, Sembiring, N. and Djoefrie, M. H. B. (2011) 'Pengaruh pemberian bahan organik pada tanah liat dan lempung berliat terhadap kemampuan mengikat air', Jurnal IImu Pertanian Indonesia, 16(2), pp. 130-135.

Kusuma, A. H., Izzati, M. and Saptiningsih, E. (2013) 'Pengaruh penambahan arang dan abu sekam dengan proporsi yang berbeda terhadap permeabilitas dan porositas tanah liat serta pertumbuhan kacang hijau (Vigna radiata L)', Buletin Anatomi dan Fisiologi, 21(1), pp. 1-9.

Makdoh, K. and Kayang, H. (2015) 'Soil physicochemical properties in coal mining areas of Khliehriat, East Jaintia Hills District, Meghalaya, India', International Research Journal of Environment Sciences, 4(10), pp. 69-76.

Masria (2015) Karakteristik pori dan hubungannya dengan permeabilitas pada tanah vertisol asal Jeneponto. Universitas Hasanuddin.

Mirdat, Patádungan, Y. S. and Isrun (2013) 'Status logam berat merkuri $(\mathrm{Hg})$ dalam tanah pada kawasan pengolahan tambang emas di Kelurahan Poboya, Kota Palu', e-Journal Agrotekbis, 1(2), pp. 127-134.

Muliawan, N. R. E., Sampurno, J. and Jumarang, M. I. (2016) 'Identifikasi nilai salinitas pada lahan pertanian di daerah Jungkat berdasarkan metode daya hantar listrik (DHL)', Prisma Fisika, IV(2), pp. 69-72.

da Ponte, N. H. T., Nunes Santos, R. I., Lima Lopes Filho, W. R., Lisboa Cunha, R., Murad Magalhães, $M$. and Alves Pinheiro, H. (2019) 'Morphological 
assessments evidence that higher number of pneumatophores improves tolerance to long-term waterlogging in oil palm (Elaeis guineensis) seedlings', Flora, 250, pp. 52-58.

doi: 10.1016/j.flora.2018.11.017.

Purnamayani, R., Hendri, J. and Purnama, H. (2016) 'Karakteristik kimia tanah lahan reklamasi tambang batubara di Provinsi Jambi', in Prosiding Seminar Nasional Lahan Suboptimal 2016. Palembang: Universitas Sriwijaya, pp. 327-334.

Sari, M. N., Sudarsono, S. and Darmawan, D. (2017) 'Pengaruh bahan organik terhadap ketersediaan fosfor pada tanahtanah kaya Al dan Fe', Buletin Tanah dan Lahan, 1(1), pp. 65-71.

Shrestha, R. K. and Lal, R. (2011) 'Changes in physical and chemical properties of soil after surface mining and reclamation', Geoderma, 161(3-4), pp. 168-176. doi: 10.1016/j.geoderma.2010.12.015.
Soepardi (2005) Masalah kesuburan tanah di Indonesia. Bogor: Institut Pertanian Bogor.

Sutanto, R. (2005) Dasar-dasar ilmu tanah: Konsep dan kenyataan. Yogyakarta: Kanisius.

Tambunan, W. A. (2008) Kajian sifat fisik dan kimia tanah hubungannya dengan produksi kelapa sawit (Elaeis guneensis, Jacq) di kebun Kwala Sawit PTPN II. Universitas Sumatera Utara. Available at: http://repository.usu.ac.id/bitstream/hand le/123456789/3950/057002004.pdf?seq uence $=1$ \&isAllowed=y.

Yuarsah, I., Handayani, E. P., Rakhmiati and Yatmin (2017) 'Restoration of soil physical and chemical properties of abandoned tinmining in Bangka Belitung Islands', Journal of Tropical Soils, 22(1), pp. 21-28. doi: 10.5400/jts.2017.v22i1.21-28. 
